\title{
Maize performance in response to tillage and weed control methods
}

\author{
Haseeb Ahmad ${ }^{1 *}$, Muhammad Shafi ${ }^{1}$, Waqas Liaqat ${ }^{1}$, Muhammad \\ Faheem Jan ${ }^{1}$, Muhammad Mehran Anjum ${ }^{1}$, Nawab Ali ${ }^{1}$ and Wazir \\ Rehan $^{2}$ \\ 1. Department of Agronomy, The University of Agriculture Peshawar, KPK-Pakistan \\ 2. Agricultural Research Institute Tarnab, Peshawar, KPK-Pakistan \\ *Corresponding author's email: haseeb@aup.edu.pk \\ Citation \\ Haseeb Ahmad, Muhammad Shafi, Waqas Liaqat, Muhammad Faheem Jan, Muhammad Mehran Anjum, Nawab Ali \\ and Wazir Rehan. Maize performance in response to tillage and weed control methods. Pure and Applied Biology. \\ Vol. 7, Issue 2, pp518-526. http://dx.doi.org/10.19045/bspab.2018.70065
}

Received: 22/02/2018

Revised: $12 / 04 / 2018$

Accepted: $14 / 04 / 2018$

Online First: 25/04/2018

\section{Abstract}

To study the impact of different tillage practices and weed control methods on weeds growth, phenology and yield of maize, an experiment was conducted at Agronomy Research Farm of The University of Agriculture Peshawar during summer 2016. The study was performed in randomized complete block design (RCBD) with split plot arrangement having four replications. Tillage practices (chisel plough + rotavator, mouldboard plough + rotavator, cultivator + rotavator and rotavator) were assigned to main plots while weed control methods (control, hoeing 15 days after sowing (DAS), hoeing 15 and 30 DAS, hoeing 15, 30 and 45 DAS, and herbicide i.e. Nicosulfuron) were assigned to sub-plots. Results revealed that treatment of chisel plough + rotavator had induced significantly early days to tasseling, silking and physiological maturity and produced maximum grain yield and biological yield as compared to other tested tillage practices. Minimum weeds $\mathrm{m}^{-2}$ and weeds fresh weight at 60 DAS was recorded from the treatment of chisel plough + rotavator. Among weed control methods, the treatment of hoeing 15, 30 and 45 DAS delayed days to tasseling, silking and physiological maturity and resulted in higher grain yield and biological yield. Hoeing 15, 30 and 45 DAS drastically reduced weeds $\mathrm{m}^{-2}$ and weeds fresh weight at 60 DAS. It is concluded that chisel plough + rotavator and hoeing at 15, 30 and 45 days after sowing (DAS) significantly improved yield of maize crop.

Keywords: Cultivator; Grain yield; Hoeing; Nicosulfuron; Rotavator

\section{Introduction}

Maize (Zea mays L.) belongs to family Poaceae, an essential cultivated cereal crop all over the world and has a great economic importance in poultry and livestock production [1]. In the year 2014-2015, in Pakistan it was grown on an area of 1142.5 thousand hectares which produced 4936.8 thousand tons grains and mean yield was
$4321 \mathrm{~kg} \mathrm{ha}{ }^{-1}$. In Khyber Pakhtunkhwa province, it was cultivated on 463 thousand hectares with a whole production of 909.7 thousand tones and mean yield was $1965 \mathrm{~kg}$ $\mathrm{ha}^{-1}[2]$.

Despite of high yielding varieties of maize and suitable production environment in Pakistan, the yield per hectare is still low. Improper tillage practices and weeds 
infestation are the key problems in declining yield of maize in Pakistan. Tillage is one of the most important components of crop production system that influences crop yield. About $20 \%$ yield contribution is due to tillage implements amongst the other crop production elements [3]. Plowing operations and disturbance of soil usually can improve soil aeration, mineralization of organic nitrogen and its availability for plant consumption [4]. A hard seedbed may possibly reduce growth of seedlings and severely disturb crop production. The success or failure of crop production system amongst different variables depends upon seedbed environment.

Weeds control is one of the utmost important factors for sustainable agriculture [5]. Weeds are unwanted plants species growing in yieldable crops. The idea of weeds as undesirable plants developed, when man began to produce plants for food and other different purposes [6]. Weeds infestation is also responsible for lower yield of the crops. Extreme weeds growth in corn field leads to 66-80\% reduction in crop yield [7]. Weeds compete for space, water, light and nutrients with main crop and thereby decreasing crop yield and increasing production cost [8]. About half of the maize yield may reduce when weeds are not sufficiently controlled [9]. Weeds can be controlled through several measures such as cultural, mechanical, biological and chemical methods.

Lacking suitable tillage practices with conventional weeds control measures are the key problems in declining yield of maize in Pakistan. Keeping in view the importance of tillage practices and weed control methods, the present research was conducted to find out suitable tillage practice(s) along with proper weed control method(s) for attaining higher maize yield.

\section{Materials and methods}

The experimental site Agronomy Research Farm of The University of Agriculture
Peshawar, Pakistan, is located at $34^{\circ} \mathrm{N}$ latitude, $71^{\circ} \mathrm{E}$ longitude with an altitude of $350 \mathrm{~m}$ above sea level and has a sub-tropical climate [10]. Soil of experimental site was alkaline $(\mathrm{pH}$ 8.02) and calcareous $\left(\mathrm{CaCO}_{3}>3 \%\right)$ in nature, low in organic matter $\left(0.845 \mathrm{~g} \mathrm{~kg}^{-1}\right)$, non-saline (EC (1:1) $0.87 \mathrm{~d} \mathrm{~S}$ $\left.\mathrm{m}^{-1}\right)$, low in available nitrogen $\left(0.04 \mathrm{~g} \mathrm{~kg}^{-1}\right)$ and phosphorous $\left(4 \mathrm{mg} \mathrm{kg}^{-1}\right)$ with nearly sufficient in potassium $\left(80 \mathrm{mg} \mathrm{kg}^{-1}\right)$. The texture of the soil was silty clay loam having $40 \%$ clay, $51.3 \%$ silt and $8.7 \%$ sand. Canal water was available for irrigation [11]. To study the weeds behavior, phenology and yield response of maize to various tillage practices and weed control methods, a field experiment was conducted during kharif season 2016. The experiment was carried out in randomized complete block design (RCBD) with split-plot arrangement. Each treatment was replicated 4 times. Tillage practices (chisel plough + rotavator, mouldboard plough + rotavator, cultivator + rotavator and rotavator) were allotted to main plots and weed control methods (control i.e. weedy check, hoeing 15 days after sowing (DAS), hoeing 15 and 30 DAS, hoeing 15, 30 and 45 DAS, and herbicide i.e. Nicosulfuron) to subplots. Azam variety of maize was sown with a seed rate of $30 \mathrm{~kg} \mathrm{ha}^{-1}$. Row to row distance was kept $0.75 \mathrm{~m}$ and plant to plant distance was maintained $0.2 \mathrm{~m}$. The sub plot size was $3 \mathrm{~m}$ x $3.75 \mathrm{~m}$. Recommended nitrogen and phosphorous was applied at the rate of 150 and $90 \mathrm{~kg} \mathrm{ha}^{-1}$ from urea and diammonium phosphate (DAP) respectively. Herbicide, Nicosulfuron was applied at the rate of $750 \mathrm{ml} \mathrm{ha}^{-1}$ to suppress both grassy weeds and broad leaf weeds. The herbicide was sprayed at 4-5 leaves stage of weeds (25 days after sowing of maize crop). All other agronomic practices were applied equally to each experimental unit. Data was recorded on Weeds $\mathrm{m}^{-2}$, weeds fresh weight at 60 days after sowing, phenology (number of days to tasseling, silking and physiological 
maturity), grain yield, biological yield and harvest index of maize. Weeds $\mathrm{m}^{-2}$ at 60 days after sowing (DAS) was determined by randomly throwing a $50 \mathrm{~cm}$ x $50 \mathrm{~cm}$ iron ring at three different places in each subplot. Number of weeds inside the ring was counted and converted into weed $\mathrm{m}^{-2}$. For weeds fresh weight, the weeds counted at 60 DAS were cut down and weighed to determine weeds fresh weight. The data was converted into $g$ $\mathrm{m}^{-2}$. Days to tasseling was recorded by counting days from the date of sowing to date when $80 \%$ plants produced tassels in each sub plot. Data on number of days to silking was recorded by counting days from the date of sowing to date when $80 \%$ plants produced silks in each subplot. Data regarding physiological maturity was taken by counting the number of days from the date of sowing to the date when $80 \%$ plants showed a black scar at the base of their grains in each sub plot. At harvest maturity three central rows in each experimental unit were harvested, sun dried and weighed with the help of an electronic balance for recording biological yield $\left(\mathrm{t} \mathrm{ha}^{-1}\right)$ data. For grain yield three central rows were harvested, threshed, cleaned and weighed with an electronic balance for computing grain yield $\left(\mathrm{t} \mathrm{ha}^{-1}\right)$. Data regarding harvest index was calculated by the following formula.

Harvest index $(\%)=$

$\frac{\text { Grain yield }\left(\mathrm{t} \mathrm{ha}^{-1}\right)}{\text { Biological yield }\left(\mathrm{t} \mathrm{ha}^{-1}\right)} \times 100$

All the collected data was analyzed statistically according to the appropriate procedure used for randomized complete block design with split plot arrangement. Least significant difference test $(\mathrm{P} \leq 0.05)$ was applied in case of significant F-test for mean comparisons to classify the significance between treatments means as described by [12].

\section{Results and discussion}

Weeds $\mathrm{m}^{-2}$ at 60 days after sowing

Table 1 reveals data regarding number of weeds $\mathrm{m}^{-2}$ at 60 days after sowing (DAS) in response to different tillage practices and weed control methods. Statistical analysis of data indicated that tillage operations and weeds control methods had significantly $(\mathrm{P} \leq 0.05)$ affected number of weeds $\mathrm{m}^{-2}$. The interaction of tillage practices and weed control methods was non-significant. Maximum weeds $\mathrm{m}^{-2}$ was observed in treatment of rotavator followed by cultivator + rotavator. Minimum number of weeds $\mathrm{m}^{-2}$ at 60 days after sowing was recorded from treatment of chisel plough + rotavator. The superiority of chisel plough to decrease weeds population at 60 days after sowing could be attributed to the presence of significantly less number of weed seeds in soil layer as compared to other tillage operations which helped the crop to take lead in its growth and establishment with suppressing the weeds growth due to less weeds density. [13-15] revealed that tillage practice (chisel plough) reduced number of weeds. Significant variations were observed in weeds $\mathrm{m}^{-2}$ with different weeds control strategies. Lowest number of weeds $\mathrm{m}^{-2}$ at 60 DAS was recorded from the treatment of three hoeings i.e. hoeing 15, 30 and 45 days after sowing followed by weeds $\mathrm{m}^{-2}$ from the application of herbicide (Nicosulfuron). Highest weeds $\mathrm{m}^{-2}$ at 60 days after sowing was recorded from control. $[16,17]$ reported that different weed control methods specifically with hoeing significantly reduced weeds population including both grassy and broad-leaf weeds in maize crop.

Weeds fresh weight $\left(\mathrm{g} \mathrm{m}^{-2}\right)$ at 60 days after sowing

Weeds fresh weight $\left(\mathrm{g} \mathrm{m}^{-2}\right)$ at 60 DAS was significantly affected by different tillage 
practices and weed control methods (Table 1). Interaction of tillage practices and weeds control methods was found non-significant. Treatment of chisel plough + rotavator resulted in minimum weeds fresh weight followed by mouldboard plough + rotavator. Maximum weeds fresh weight at 60 days after sowing was recorded from treatment of rotavator. [13] revealed that chisel plough significantly decreased weeds fresh weight as compared to operation of rotavator. $[18,19]$ reported that majority of weeds $(71 \%)$ are concentrated in soil at the depth of $10-15 \mathrm{~cm}$ which can be disturbed greatly by deep tillage (chisel plough) operations. Lowest fresh weeds biomass was recorded from the treatment of hoeing at 15,30 and 45 DAS followed by application of herbicide (Nicosulfuron). Highest fresh weeds biomass at 60 DAS was recorded from control. [20, 21] revealed that various weeds control methods at different stages significantly reduced weeds fresh weight.

Table 1. Weeds $\mathrm{m}^{-2}$ at $60 \mathrm{DAS}$, weeds fresh weight $\left(\mathrm{g} \mathrm{m}^{-2}\right)$ at $60 \mathrm{DAS}$, days to tasseling, silking and physiological maturity of maize as affected by different tillage practices and weed control methods.

\begin{tabular}{|c|c|c|c|c|c|}
\hline Tillage Practices & $\begin{array}{l}\text { Weeds } \mathrm{m}^{-2} \\
\text { at } 60 \mathrm{DAS}\end{array}$ & $\begin{array}{c}\text { Weeds fresh } \\
\text { weight }\left(\mathrm{g} \mathrm{m}^{-2}\right) \text { at } \\
60 \mathrm{DAS} \\
\end{array}$ & $\begin{array}{l}\text { Days to } \\
\text { tasseling }\end{array}$ & $\begin{array}{l}\text { Days to } \\
\text { silking }\end{array}$ & $\begin{array}{c}\text { Days to } \\
\text { physiological } \\
\text { maturity } \\
\end{array}$ \\
\hline Chisel plough + Rotavator & $125 \mathrm{~d}$ & $252.56 \mathrm{c}$ & $52 \mathrm{c}$ & $57 \mathrm{c}$ & $89 \mathrm{c}$ \\
\hline $\begin{array}{c}\text { Mouldboard plough }+ \\
\text { Rotavator }\end{array}$ & $159 \mathrm{c}$ & $312.82 \mathrm{~b}$ & $53 \mathrm{~b}$ & $58 \mathrm{~b}$ & $91 \mathrm{~b}$ \\
\hline Cultivator + Rotavator & $189 \mathrm{~b}$ & $361.54 \mathrm{a}$ & $53 \mathrm{~b}$ & $58 \mathrm{~b}$ & $92 \mathrm{~b}$ \\
\hline Rotavator & $211 \mathrm{a}$ & $370.22 \mathrm{a}$ & $54 \mathrm{a}$ & $59 \mathrm{a}$ & $93 \mathrm{a}$ \\
\hline \multicolumn{6}{|l|}{ Weed control methods } \\
\hline Control & $249 \mathrm{a}$ & $505 \mathrm{a}$ & $51 \mathrm{~d}$ & $56 \mathrm{~d}$ & $90 \mathrm{c}$ \\
\hline Hoeing 15 DAS & $219 b$ & $424.91 \mathrm{~b}$ & $52 \mathrm{c}$ & $57 \mathrm{c}$ & $91 \mathrm{~b}$ \\
\hline Hoeing 15 and 30 DAS & $150 \mathrm{c}$ & $264.53 \mathrm{c}$ & $53 \mathrm{~b}$ & $58 \mathrm{~b}$ & $91 \mathrm{~b}$ \\
\hline Hoeing 15,30 and 45 DAS & $93 \mathrm{~d}$ & $173.97 \mathrm{~d}$ & $55 \mathrm{a}$ & $60 \mathrm{a}$ & $93 \mathrm{a}$ \\
\hline Nicosulfuron & $144 \mathrm{c}$ & $253.02 \mathrm{c}$ & $53 \mathrm{~b}$ & $58 \mathrm{bc}$ & $91 \mathrm{~b}$ \\
\hline $\operatorname{LSD}_{(0.05)}$ for TP & 21 & 37.72 & 0.74 & 0.57 & 1.33 \\
\hline $\operatorname{LSD}_{(0.05)}$ for $\mathrm{WCM}$ & 10 & 21.92 & 0.87 & 0.86 & 0.84 \\
\hline TP $\times$ WCM & $\mathrm{ns}$ & ns & $\mathrm{ns}$ & ns & ns \\
\hline
\end{tabular}

Means in same column followed by same letter(s) are statistically similar at $5 \%$ level of significance.

DAS $=$ Days after sowing, $\mathrm{TP}=$ Tillage practices, $\mathrm{WCM}=$ Weed control methods, $n s=$ non-significant

\section{Days to tasseling}

Data pertaining to number of days to tasseling in maize as affected by different tillage practices and weed control methods is shown in Table 1. Early tasseling was observed in the treatment of chisel plough + rotavator followed by cultivator + rotavator which was statistically similar with mouldboard plough + rotavator. Treatment of rotavator resulted in delayed tasseling. Early tasseling might be due to more favorable soil environment such as breaking of hard pan through chisel plough which improved soil aeration and released efficient nutrients for the development of crop. Our results are in agreement with [22] who reported that as tillage depth increases the number of days to tasseling decreases. Among weed control 
methods, the delayed tasseling were recorded from the treatment of hoeing 15, 30 and 45 days after sowing (DAS) followed by days to tasseling from treatment of hoeing 15 and 30 DAS which was statistically similar with the application of Nicosulfuron. Early tasseling was recorded for control (weedy check). It may be attributed to efficient weeds control and lower weeds-crop competition in terms of moisture, uniform solar radiation, space and nutrients for plant growth. [23] reported that weeds free plots significantly delayed time taken to $50 \%$ tasseling.

\section{Days to silking}

Number of days to silking in maize as influenced by different tillage practices and weed control methods is presented in Table 1. Less days to silking was recorded from the treatment of chisel plough + rotavator followed by mouldboard plough + rotavator which was not significantly different from cultivator + rotavator. Maximum days to silking were observed in treatment of rotavator. This might be due to early tasseling and more favorable conditions provided by chisel plough + rotavator. Similar results were declared by [24]. Among weed control methods, the treatment of hoeing 15, 30 and 45 DAS showed maximum days to silking followed by treatment of hoeing 15 and 30 DAS. Lowest number of days to silking was noted from control plots. The 3 hoeing efficiently controlled weeds density which led to less weed-crop competition and ensured more water and nutrients availability for crop plants. The maize crop has got the opportunity for maximum utilization of soil and environmental resources for growth and hence took more days to attain the stage of silking. [23] reported that weeds free plots significantly delayed time taken to $50 \%$ silking in maize crop.

\section{Days to physiological maturity}

Significant variations were recorded in days to physiological maturity of maize as influenced by different tillage operations and weed control methods (Table 1). Mean values of the data showed that treatment of chisel plough + rotavator induced early physiological maturity of maize crop followed by mouldboard plough + rotavator. Delayed physiological maturity was recorded from treatment of rotavator. [22] recorded early physiological maturity in the plots ploughed with chisel plough. Among weed control methods, treatment of hoeing 15, 30 and 45 DAS took more number of days till physiological maturity followed by the application of Nicosulfuron which was statistically at par with the treatment of hoeing 15 and 30 DAS. Minimum days to physiological maturity were recorded from control. [25] reported that different weed control measures have significantly increased number of days to physiological maturity.

\section{Biological yield (t ha-1)}

Table 2 presents data regarding biological yield of maize crop as affected by tillage practices and weed control methods. Mean values revealed that highest biological yield was harvested from the treatment of chisel plough + rotavator. Treatment of mouldboard plough + rotavator ranked $2^{\text {nd }}$ in the production of biological yield. Lowest biological yield was recorded from the treatment of rotavator. The possible reason for more biological yield due to chisel plough might be attributed to the good soil conditions such as softened seedbed preparation, good soil aeration, increased infiltration rate, availability of nutrients and moisture. The operation of rotavator destroyed the weeds that provided more favorable environment for crop plants to efficiently utilize the available soil moisture, nutrients, space and solar radiation. Our results are in line with those of [26, 27]. Among weed control methods, significantly highest biological yield was obtained from treatment of hoeing at 15, 30 and 45 DAS followed by the treatment of hoeing at 15 and 30 DAS which was statistically similar with 
the application of herbicide i.e. Nicosulfuron. Lowest biological yield was harvested from the control. It could be due to less weeds infestation, low crop-weeds competition for resources, higher nutrients and moisture uptake by crop. $[28,29]$ reported that various weeds control methods significantly improved biological yield of maize.

Table 2. Biological yield $\left(\mathrm{t} \mathrm{ha}^{-1}\right)$, grain yield $\left(\mathrm{t} \mathrm{ha}^{-1}\right)$ and harvest index (\%) of maize as affected by different tillage practices and weed control methods

\begin{tabular}{|c|c|c|c|}
\hline Tillage Practices & Biological yield $\left(\mathrm{t} \mathrm{ha}^{-1}\right)$ & Grain yield $\left(\mathrm{t} \mathrm{ha}^{-1}\right)$ & Harvest index (\%) \\
\hline Chisel plough + Rotavator & $11.98 \mathrm{a}$ & $3.41 \mathrm{a}$ & 28.62 \\
\hline Mouldboard plough + Rotavator & $11.24 \mathrm{~b}$ & $3.15 \mathrm{~b}$ & 28.33 \\
\hline Cultivator + Rotavator & $10.38 \mathrm{c}$ & $2.97 \mathrm{~b}$ & 28.81 \\
\hline Rotavator & $9.49 \mathrm{~d}$ & $2.69 \mathrm{c}$ & 28.77 \\
\hline \multicolumn{4}{|l|}{ Weed control methods } \\
\hline Control & $9.18 \mathrm{~d}$ & $2.62 \mathrm{~d}$ & 28.69 \\
\hline Hoeing 15 DAS & $10.01 \mathrm{c}$ & $2.93 \mathrm{c}$ & 29.83 \\
\hline Hoeing 15 and 30 DAS & $11.29 \mathrm{~b}$ & $3.18 \mathrm{~b}$ & 28.26 \\
\hline Hoeing 15,30 and 45 DAS & $12.35 \mathrm{a}$ & $3.49 \mathrm{a}$ & 28.38 \\
\hline Nicosulfuron & $11.04 \mathrm{~b}$ & $3.05 \mathrm{bc}$ & 27.99 \\
\hline $\operatorname{LSD}_{(0.05)}$ for $T P$ & 0.707 & 0.22 & ns \\
\hline $\operatorname{LSD}_{(0.05)}$ for WCM & 0.765 & 0.248 & ns \\
\hline TP x WCM & ns & ns & ns \\
\hline
\end{tabular}

Means in same column followed by same letter(s) are statistically similar at 5\% level of significance

DAS $=$ Days after sowing $\mathrm{TP}=$ Tillage practices, $\mathrm{WCM}=$ Weed control methods, $\mathrm{ns}=$ non -significant

\section{Grain yield (t ha' $\left.\mathbf{~}^{-1}\right)$}

Grain yield of maize was significantly influenced by different tillage practices and weed control methods (Table 2). The treatment of chisel plough + rotavator produced highest grain yield of maize followed by the treatment of mouldboard plough + rotavator. Lowest grain yield was recorded from treatment of rotavator. Chisel plough is very effective in breaking the hard pan of compacted soil which provides favorable environment for enhanced root growth. The operation of rotavator crushed, grinded and buried the weeds in the soil which later on served as organic matter for current maize crop. [30, 31] reported the positive impact of tillage treatment (chisel plough + rotavator) on soil physical properties which might led to higher grain yield of maize. Among weeds control methods, hoeing 15, 30 and 45 days after sowing (DAS) produced highest grain yield of maize, followed by grain yield obtained from the treatment of hoeing 15 and 30 DAS which was statistically similar with the application of herbicide (Nicosulfuron). Lowest grain yield was harvested from control (Weedy check). It is revealed that harvest of higher grain yield was due to efficient weeds control, minimum weeds population and minimum weeds-crop competition in terms of moisture, solar radiation, space and nutrients. Similar results were declared by $[28,32]$ who reported that various weed control methods specifically with hoeing significantly enhanced grain yield of maize crop. 


\section{Harvest index (\%)}

Harvest index of maize was neither significantly affected by various tillage practices nor by different weed control methods (Table 2). All the means were statistically similar. Our findings agree with the results of [33] who reported that different tillage practices had a non-significant effect on harvest index of maize.

\section{Conclusion}

From the research conducted, it can be concluded that among various studied tillage practices, treatment of chisel plough + rotavator resulted in maximum biological and grain yield with minimum weeds $\mathrm{m}^{-2}$ and weeds fresh weight at 60 days after sowing (DAS). Among weed control methods, hoeing at 15, 30 and 45 DAS produced highest grain yield of maize and also reduced weeds $\mathrm{m}^{-2}$ and weeds fresh weight at 60 DAS. Thus, ploughing field with chisel plough + rotavator and 3 hoeing i.e. hoeing at 15, 30 and 45 days after sowing is recommended for obtaining higher maize yield under the agro-climatic conditions of Peshawar region.

\section{Authors' contributions}

Conceived and designed the experiments: $\mathrm{M}$ Shafi, Performed the experiments: H Ahmad, W Liaqat \& MF Jan, Analyzed the data: H Ahmad \& W Liaqat, Contributed materials/ analysis/ tools: MM Anjum, N Ali \& W Rehan, Wrote the paper: H Ahmad \& W Liaqat

\section{References}

1. Harris D, Rashid A, Miraj G, Arif M \& Shah H (2007). On-farm seed priming with zinc sulphate solution-A costeffective way to increase the maize yields of resource-poor farmers. Field Crops Res 102: 119-127.

2. MNFSR (2015). Agricultural Statistics of Pakistan. Ministry of National Food Security and Research (Economic wing) Govt. of Pakistan. Islamabad.

3. Khurshid K, Iqbal M, Arif MS \& Nawaz A (2006). Effect of tillage and mulch on soil physical properties and growth of maize. Int J Agric Biol 8(5): 593-596.

4. Dinnes DL, Karlen DL, Jaynes DB, Kaspar TC, Hatfield JL, Colvin TS \& Cambardella CA (2002). Nitrogen management strategies to reduce nitrate leaching in tile-drained Midwestern soils. Agron J 94: 153-171.

5. Arif M, Ali K, Haq MS \& Khan Z (2013). Biochar, FYM and nitrogen increase weeds infestation in wheat. Pak J Weed Sci Res 19(4): 411-418.

6. Dangwal LR, Singh A, Singh T, Sharma A \& Sharma C (2010). Common weeds of Rabi (winter) crops of tehsil Nowshera, District Rajouri (Jammu \& Kashmir), India. Pak J Weed Sci Res 16(1): 39-45.

7. Adigun JA (2001). Control of weeds with pre-emergence herbicides in maizepepper mixture in the Nigerian northern Guinea Savanna. J Sustainable Agric Environ 3: 378-383.

8. Shah WA, Khan MA, Khan N, Zarkoon MA \& Bakht J (2003). Effect of weed management at various growth stages on the yield and yield components of wheat (Triticum aestivum L.). Pak J Weed Sci Res 9(2): 41-48.

9. Chikoye D, Ekeleme F \& Udensi UE (2001). Cogon grass suppression by intercropping cover crops in corn/cassava systems. Weed Sci 49: 658-667.

10. Bakht J, Shafi M, Jan MT \& Shah Z (2009). Influence of crop residue management, cropping system and $\mathrm{N}$ fertilizer on soil $\mathrm{N}$ and $\mathrm{C}$ dynamics and sustainable wheat (Triticum aestivum L.) production. Soil Till Res 104: 233-240.

11. Ahmad H, Shafi M, Liaqat W, Jan MF \& Rehan W (2018). Effect of tillage practices and weed control methods on yield and yield components of maize. Middle East J Agric Res 7(1): 175-181.

12. Jan MT, Shah P, Hollington PA, Khan MJ \& Sohail Q (2009). Agriculture Research: 
Design and Analysis, A monograph. Agric Univ Pesh Pak.

13. Khan MA, Basir A, Adnan M, Shah AS, Noor M, Khan A, Shah JA, Ali Z \& Rahman A (2017). Wheat phenology and density and fresh and dry weight of weeds as affected by potassium sources levels and tillage practices. Pak J Weed Sci Res 23(4): 451-462.

14. Demjanova E, Macak M, Alovi I, Majernik F, Tyr S \& Smatana J (2009). Effects of tillage system systems and crop rotation on weed density, weed species composition and weed biomass in maize. Agron Res 7(2): 785-792.

15. Arif M, Munsif F, Waqas M, Khalil IA \& Ali K (2007). Effect of tillage on weeds and economics of fodder maize production. Pak J Weed Sci Res 13(3): 167-175.

16. Ali S, Shahbaz M, Nadeem MA, Ijaz M, Haider MS, Anees M \& Khan HAA (2014). The relative performance of weed control practices in September sown maize. Mycopath Res Article 12(1): 4351.

17. Hassan AAA \& Ahmed MKA (2005). The influence of some herbicides and additional hoeing in maize growth and yield and yield components. Int J Agric Bio 7(5): 708-711.

18. Nakamoto $\mathrm{T}$, Yamagishi J \& Miura $\mathrm{F}$ (2006). Effect of reduced tillage on weeds and soil organism in winter wheat and summer maize cropping on humicandosols in central Japan. Soil Tillage Res 85: 94-106.

19. Swanton CJ, Shrestha A, Knezevic SZ, Roy RC \& Ball-Coello BR (2000). Influence of tillage type on vertical weed seed bank distribution in a sandy soil. Can J Plant Sci 80: 455-457.

20. Khatam A, Khan MZ, Nawab K, Mian IA \& Ahmad W (2013). Effect of various herbicides and manual control on yield, yield components and weeds of maize. Pak J Weed Sci Res 19(2): 209-216.

21. Kandil EEE \& Kordy AM (2013). Effect of hand hoeing and herbicides on weeds growth, yield and yield components of maize (Zea mays L.). J App Sci Res 9(4): 3075-3082.

22. Anjum SA, Ehsanullah, Ashraf U, Tanveer M, Qamar R \& Khan I (2014). Morphological and phenological attributes of maize affected by different tillage practices and varied sowing methods. Am J Plant Sci 5: 1657-1664.

23. Saeed M, Khaliq A, Cheema ZA \& Ranjha AM (2010). Effect of nitrogen levels and weed-crop competition durations on yield and yield components of maize. J Agric Res 48(4): 471-481.

24. Javeed HMR, Zamir MSI, Nadeem M, Qamar R, Shehzad M, Sarwar MA \& Iqbal S (2014). Response of maize phenology and harvest index to tillage and poultry manure. Pak J Agric Sci 51(3): 633-638.

25. Ali S, Akmal M \& Afzal M (2015). Seedbed preparation time and weeding intervals and their response on maize yield and traits in KP-Pakistan. Basic Res J Agric Sci Rev 4(1): 14-20.

26. Shahid MN, Zamir MSI, Haq IU, Khan MK, Hussain M, Afzal U, Asim M \& Ali I (2016). Evaluating the impact of different tillage regimes and nitrogen levels on yield and yield components of maize (Zea mays L.). Am J Plant Sci 7: 789-797.

27. Memon SQ, Mirjat MS, Mughal AQ \& Amjad N (2013). Effect of conventional and non-conventional tillage practices on maize production. Pak J Agric 29(2): 155163.

28. Din WU, Naveed K, Iqbal S, Ali A, Khan SM, Ali N \& Hussain I (2016). Effect of different weeding intervals and methods on the yield and yield components of 
maize hybrid. J Agric Bio Sci 11(3): 100106.

29. Sampaio HN, Silva PSL, Monteiro AL, Tavella LB \& de Oliveira VR (2015). Weed management in maize using hoeing and intercropping with Mimosa caesalpiniifolia. $R$ Bras Eng Agric Ambiental 19(6): 541-547.

30. Wang XH Wu, Dai K, Zhang D, Feng Z, Zhao Q, Wu X, Jin K, Cai D, Oenema O \& Hoogmoed WB (2012). Tillage and crop residue effects on rainfed wheat and maize production in northern China. Field Crops Res 132: 106-116.
31. Wasaya A, Tahir M, Manaf A, Ahmed M, Kaleem S \& Ahmad I (2011). Improving maize productivity through tillage and nitrogen management. Afr J Biotech 10: 19025-19034.

32. Tesfay A, Amin M \& Mulugeta N (2014). Management of weeds in maize ( $\mathrm{Zea}$ mays L.) through various pre and post emergency herbicides. Adv Crop Sci Tech 2(5): 151-155.

33. Amin M, Khan MJ \& Jan MT (2013). Effect of tillage practices and sowing methods on weeds and biological yield of wheat under semi-arid environment. Pak $J$ Weed Sci Res 19(1): 109-121. 